\title{
On the Nutritive Value of Pentosan. III.
}

The Glycogen Accumulation in the Body of Rats by the Xylan Feeding.

By

Hisayoshi IwaTa.

(From the Laboratory of Biochemisiry, Moriska Imperial C'ollege of Agriculture and Forestry.)

(Received May 30, 1932.)

In a previous communication of this investigation ${ }^{(2)}$ it was concluded that the total amount of glycogen accumulated in the body of rabbit, when xylan was administered, is nearly equal to that accumulated by the administration of the same amount of starch. In this paper a brief report is made on the effect of xylan feeding upon the glycogen content in the albino rat, which were selected as an example of omnivorous animals.

\section{Experimental.}

Young albino rats were divided into three groups, one of them was subjected to a fasting test, the other to a xylan feeding test, and the latter to a starch feeding test as a collateral. The detail of the experimental procedure was nearly equal as described in the second report of this investigation. The results obtained in ragard to both the glycogen content and blood constituents, which were also studied in this connection, may be shown in Table I, II, III.

Table I. The fasting test.

\begin{tabular}{|c|c|c|c|c|c|}
\hline Date. $(1930 \sim 1932)$ & '30. Oct. 1 & Oct. 28 & Oit. 31 & '31. Jan. 29 & Jan. 30 \\
\hline Sex of albino rat. & nale & male & female & remale & female \\
\hline Hours fasted. & 25.5 & 24.0 & 24.0 & 24.5 & 24.0 \\
\hline Budy weight, g. & 208 & 180 & 105 & 133 & 149 \\
\hline Liver weight, $\mathrm{g}$. & 8.4 & 10.5 & 4.5 & 7.0 & 7.8 \\
\hline Liver glycogen, $\mathrm{mg}$. in $100 \mathrm{mg}$. & 11 & 37 & 32 & 60 & 41 \\
\hline Muscle weight (calculated), $\mathrm{g}$. & 97.8 & 84.6 & 49.4 & 62.5 & 70.0 \\
\hline Muscle glycogen, $\mathrm{mg}$. in $100 \mathrm{~g}$. & 21 & 25 & 105 & 274 & 118 \\
\hline Total glycogen, in $100 \mathrm{~g}$. body. & 10.3 & 14.0 & 50.6 & 132.0 & 57.6 \\
\hline Do. average. & \multicolumn{2}{|c|}{12.2} & \multicolumn{3}{|c|}{80.1} \\
\hline Total blood sugar, mg. in $100 \mathrm{c}, \mathrm{c}$. & - & - & -106 & 96 & 98 \\
\hline Nonfermentable sugar, $\quad "$ & - & - & - & - & 33 \\
\hline Nonprotein nitrogen. & - & - & - & 54 & 38 \\
\hline Itaemoglohin. $\%$ & - & 一 & 17.1 & 17.3 & 17.2 \\
\hline
\end{tabular}


Table II. The xylan feeding test.

\begin{tabular}{|c|c|c|c|c|c|c|c|}
\hline \\
\hline $\begin{array}{l}\text { Date (1930 1932). } \\
\text { Sex of albino rat. }\end{array}$ & $\begin{array}{c}1930 \\
9,20 \\
\mathrm{~m} .\end{array}$ & $\begin{array}{c}1930 \\
10 ., 1 \\
\mathrm{f} .\end{array}$ & $\begin{array}{l}1931 \\
3,21 \\
\mathrm{f} .\end{array}$ & $\begin{array}{l}1932 \\
4,18 \\
f .\end{array}$ & $\begin{array}{l}1930 \\
10,3 \\
f .\end{array}$ & $\begin{array}{l}1931 \\
1,29 \\
f .\end{array}$ & $\begin{array}{l}1931 \\
1,30 \\
\mathrm{f} .\end{array}$ \\
\hline Hours fasted. & 23.5 & 20.0 & 24.0 & 22.0 & 9.0 & 8.0 & 8.0 \\
\hline Hours, fed to killed. & 2.0 & 3.5 & 2.0 & 2.0 & 16.0 & 18.0 & 16.0 \\
\hline Hours, fasting begun to killed. & 25.5 & 23.5 & 26.0 & 24.0 & 25.0 & 26.0 & 24.0 \\
\hline Body weight, g. & 152 & 115 & 180 & 145 & 94 & 134 & 145 \\
\hline Xylan eaten, $\mathrm{g}$. & 2.0 & 2.4 & 2.0 & 1.9 & 3.0 & 2.5 & 2.4 \\
\hline I.iver weight, g. & 6.2 & 5.0 & 7.1 & 7.0 & 3.7 & 7.0 & 7.2 \\
\hline Liver glycogen, mg. in $100 \mathrm{~g}$. & 15 & 46 & 57 & 61 & 64 & 128 & 115 \\
\hline Muscle weight (calculated), g. & 71.4 & 54.1 & 84.6 & 68.2 & 44.2 & 63.0 & 68.2 \\
\hline Muscle glycogen, mg. in $100 \mathrm{~g}$. & 16 & 173 & 165 & 171 & 158 & 256 & 148 \\
\hline Total glycogen in $100 \mathrm{~g}$. body. & 8.1 & $\underbrace{83.3}$ & 29.8 & 83.4 & 76.8 & 127.0 & 75.2 \\
\hline Do. average. & 8.1 & \multicolumn{3}{|c|}{82.2} & \multicolumn{3}{|c|}{93.0} \\
\hline Do. increase compared with fast. & -4.1 & \multicolumn{3}{|c|}{2.1} & \multicolumn{3}{|c|}{12.9} \\
\hline Do. increase per $1 \mathrm{~g}$. xylan. & -3.1 & \multicolumn{3}{|c|}{1.4} & \multicolumn{3}{|c|}{5.8} \\
\hline Total blood sugar mg. in $100 \mathrm{ccc}$. & - & 100 & 98 & 90 & 86 & 104 & 95 \\
\hline Nonfermentable blood sugar. " & - & - & 34 & 一 & - & 36 & 32 \\
\hline Nonprotein nitrogen. & - & - & 40 & 38 & - & 49 & 38 \\
\hline Haemoglobin. \% & - & - & 17.9 & 16.9 & 17.9 & 16.9 & 17.4 \\
\hline Xylan recovered from dig. tract. & - & - & 1.83 & 1.50 & - & - & 1.45 \\
\hline
\end{tabular}

Table III. The starch feeding test.

\begin{tabular}{|c|c|c|c|c|c|}
\hline Date. $(1930 \sim 1932)$ & '30. Sep. 2 & 2. Mar. 29 & Apr. 18. & '30. Oct. 31 & 31. Jan. 31 \\
\hline Sex of albino rat. & nale & female & female & female & female \\
\hline Hours fasted. & 24 & 24 & 22 & 9 & 8 \\
\hline Itours, fed to killed. & 2 & 2 & 2.5 & 16 & 16 \\
\hline Hours, fasting begun to killed. & 26 & 26 & 24.5 & 25 & 24 \\
\hline Body weight, g. & 184 & 175 & 140 & 111 & 143 \\
\hline Starch eaten, $\mathrm{g}$. & 4 & 4 & 4 & 4 & 2 \\
\hline Liver weight, $\mathrm{g}$. & 7.8 & 7.2 & 7.2 & 4.7 & 7.1 \\
\hline Liver glycogen, mg. in $100 \mathrm{~g}$. & 1060 & 1394 & 1470 & 1284 & 214 \\
\hline Muscle weight (calculated), g. & 86.5 & 82.3 & 65.8 & 52.2 & 67.2 \\
\hline Muscle glocogen, $\mathrm{mg}$. in $100 \mathrm{~g}$. & 452 & 391 & 264 & 247 & 94 \\
\hline Total glycogen in $100 \mathrm{~g}$. body. & 257.4 & 241.3 & 199.3 & 170.5 & 54.8 \\
\hline Do, average. & 257.4 & \multicolumn{2}{|c|}{220.3} & \multicolumn{2}{|c|}{$\mathrm{P}_{112.7}$} \\
\hline Do, increase compared with fast. & 245.2 & \multicolumn{2}{|c|}{140.2} & \multicolumn{2}{|c|}{32.6} \\
\hline Do. increase per $1 \mathrm{~g}$. starch. & 113.0 & \multicolumn{2}{|c|}{54.6} & \multicolumn{2}{|c|}{13.0} \\
\hline Total blood sugar, mg. in $100 \mathrm{c.c}$. & - & 109 & 112 & 115 & 103 \\
\hline Nonfermentable blood sugar. " & - & 32 & - & - & 31 \\
\hline
\end{tabular}




\begin{tabular}{|c|c|c|c|c|c|}
\hline $\begin{array}{l}\text { Nonprotein nitrogen, mg. in } 100 \mathrm{c} . c \text {, } \\
\text { Haemoglobin. \% }\end{array}$ & $\overline{17.4}$ & $\begin{array}{c}40 \\
17.1\end{array}$ & $\begin{array}{c}39 \\
16.8\end{array}$ & $\begin{array}{c}45 \\
17.2\end{array}$ & $\begin{array}{c}39 \\
16.9\end{array}$ \\
\hline Starch recovered from dig. tract. & - & 2.07 & 1.95 & - & 0.3 \\
\hline
\end{tabular}

The increase in the amount of glycogen by xylan feeding is found to be very small when compared with that in the case of starch feeding. The amount of absorbed xylan too is much smaller than that of absorbed starch. This, by the way, is a fact never noticed in the case of rabbits as was communicated in the first and second report ${ }^{(1)(2)}$. Therefore, sueh a comparison should be based on the amount of substances absorbed. The digestibility of xylan two hours after the feeding was found to be $14.6 \%$, and that of starch $49.8 \%$. The digestibilities 16 hours after the feeding were not estimated then. Ordinary digestibility coefficients were, therefore, estimated afterwards, detail accounts of which will be reported in the next paper, but the results are briefly as follows : xylan $33.1 \%$, starch $86.2 \%$. These digestibility coefficients may be applied, for the comparison without any appreciable error, to the case of 16 hours after the feeding. Thus the increase in the amount of glycogen per gram of digested xylan or starch may be shown in Table IV. and figure.

Table IV The glycogen increase per gram of digested xylan.

\begin{tabular}{|c|c|c|c|c|c|c|}
\hline & \multicolumn{3}{|c|}{ Xylan feeding. } & \multicolumn{3}{|c|}{ Starch feeding. } \\
\hline & one $\$$ & $\begin{array}{c}\text { av. three } \\
\text { 우 }\end{array}$ & $\begin{array}{c}\text { av. three } \\
\text { 오 }\end{array}$ & one $\hat{\sigma}$ & $\begin{array}{l}\text { av. two } \\
\text { 우 }\end{array}$ & 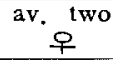 \\
\hline Hours after the feeding. & 2.0 & 2.5 & 16.6 & 2.0 & 2.3 & 16.0 \\
\hline Glycogen increase $\mathrm{mg}$. & neg. & 96 & 18 & 227 & 127 & 15 \\
\hline
\end{tabular}

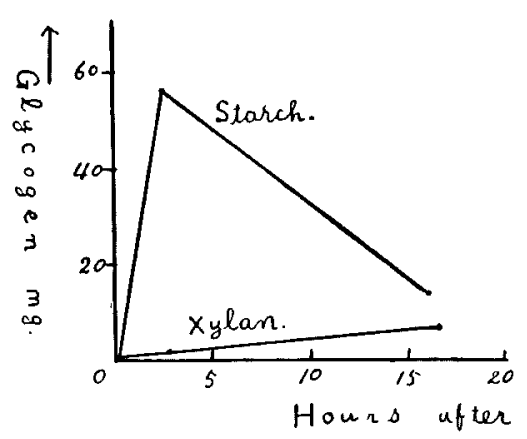

Fig. I. Glycogen increase per gram of eaten material.

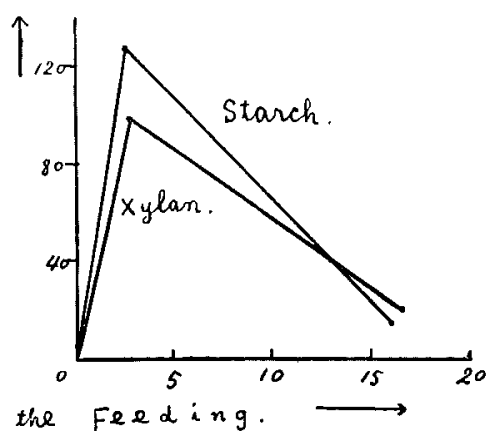

Fig. II. Glycogen increase per gram of digested material.

\section{Conclusion.}

1. Glycogen could be accumulated in the body of albino rat by the 
feeding of xylan. The accumulation, however, is very small in comparison with the application of starch. This may be attributed mainly to the difficulty in the digestion of xylan by rats. Accordingly, the increase in the amount of glycogen per gram of digested xylan is never so much small in comparison with that caused by the starch.

2. So far as the amounts of nonfermentable sugar, nonprotein nitrogen and haemoglobin are concerned, there was no appreciable difference noticed in the blood of rats, when examined at the end of either 2.5 or 16 hours after the feeding of xylan or starch or none of them. The total blood sugar, however, was found decreased somewhat in the case of xylan.

Biblography.

(1) Iwata: This journal, Vol. 7, p. 35 (1931).

(2) Do. Du, Do. p. 33 (1931).

On the Nutritive Value of Pentosan. IV.

The Methods of Treatments and the Kinds of Animals as two of the Effecting Factors upon the Digestibility of Pentosan.

By

Hisayoshi Iwata.

(From the Laboratory of Biochemistry, Norioka Imperial College of Agriculture and Forestry.)

(Received May 30, 1930.)

The effect of various treatments, such as disintegration with alkaline solutions etc., upon the digestibility of pentosan was studied, using various gramineae straws which were recently applied to the investigation of strawdisintegration by the author ${ }^{(1-5)}$. The results obtained are shown in Table $I$. The effects upon the digestibility of crude fiber and nitrogen free extract may be added here for a reference.

Table I.

The effect of variuus treatments upon the digestibility of pentosan.

\begin{tabular}{l|c|c|c|c}
\hline \multicolumn{1}{c|}{ Materials and treatments. } & $\begin{array}{c}\text { Digestibility } \\
\text { of pentosan } \\
\text { by sheep } \\
\text { av. \% }\end{array}$ & \multicolumn{2}{|c|}{ Ratio of digestibility (untreated, as 100) } \\
\cline { 1 - 5 } & Pentosan & Crude fiber & N. free ext. \\
\hline Rice straw, untreated. & 52.6 & 100 & 100 & 100 \\
Do. soaked 4 hours in $0.25 \% \mathrm{NaOH}$ & 53.7 & 102 & 101 & 87 \\
Do. soaked 4 hours in $0.75 \% \mathrm{NaOH}$ & 82.9 & 158 & 141 & 153 \\
Do. soaked 4 hours in $1.5 \% \mathrm{NaOH}$ & 82.1 & 156 & 139 & 156
\end{tabular}

